\title{
Research on Incentive System for Teaching and Research Team in Universities
}

\author{
Haiyan Gao \\ Yulin University, Yulin, Shanxi, 719000, P.R. China \\ 932864974@qq.com
}

Keywords: Teaching and research team; Incentive system; Situation; Countermeasures

\begin{abstract}
Development of teaching and research team is the key of university progress. Therefore, an incentive to teaching and research team is extremely important. Necessity of motivating the teaching and research team was discussed firstly in this paper. Secondly, current situations were analyzed and new solutions were proposed.
\end{abstract}

\section{Introduction}

China's further economic opening up and the national economic transition cause huge changes to both domestic and foreign environments, which brings universities unprecedented opportunities and challenges [1]. Meanwhile, it is necessary to have corresponding incentive system to guide behaviors of teachers because of the poor overall academic atmosphere and low enthusiasm of teachers in universities. Perfection of the incentive system is crucial to management since it is related with practical benefits and feelings of teachers and will influence innovations of universities directly. Therefore, incentives to teaching and research team in universities become the most important task of university management [2].

\section{Necessity to Perfect Incentive System for Teaching and Research Team in Universities}

Perfect Incentive System for Teaching and Research Team in Universities and Create Modern Innovative Universities. To create modern innovative universities, it is necessary to train the teaching and research team, get more achievements and further promote long-term development of universities. Universities shall stick to using incentive measures to solve problem, promoting incentive system reforms, and eliminating system defects that restrict initiatives, enthusiasm and creativity of teachers. Besides, they shall persist to the principle of efficiency priority and respect to labor, intellectual talents and creativity, and form an atmosphere and system environment that encourage reform and innovation, more pay for more work and full use of abilities of every teacher.

Perfect Incentive System for Teaching and Research Team in Universities and Enhance Sense of Belonging of Teachers. Effective incentive system can promote teachers' creativity and quality improvement, which are good for increasing their working ability and efficiency. Therefore, to establish an effective incentive system, it must follow the principle of people oriented, respect, understand and care for teachers, and enhance their sense of belonging. With the development of scientific technologies and IT, talents with innovation consciousness and ability are more and more appreciated by universities. Universities pay more and more attentions to human resources development and management. Establishing an effective incentive system for teaching and research team in universities not only can create infinite values, but also can help universities to attract excellent talents.

Perfect Incentive System for Teaching and Research Team in Universities and Give Full Play to the Qualification-based Appointment System of Universities. Managers and employees at all levels in universities shall be aware of their duties, responsibilities and powers. They have the right to get corresponding salaries matching with their abilities, qualification and duties. The teaching and research team can make a good demonstration to universities by implementing the incentive system or 
optimized incentive system, thus enabling to reflect the essence of more pay for more work, avoid "standard" idea of managers and "work according to payment" of teacher, and realize acting based on rules.

Perfect Incentive System for Teaching and Research Team in Universities and Create a Positive Competition Environment. Innovative incentive system of universities contains the spirit of competition and thereby could create a positive competition environment, forming a positive competition system. As the most important one in universities, teacher quality competition is manifested by quality competition of teaching and research teams. Such competitive pressure will turn into momentum as long as it was perceived by the teaching and research teams. Specifically, it is the competitive system of appointing people by abilities in universities.

\section{Current Situation and Problem Analysis}

Except for a loose external environment, internal management, especially incentive management, is the key of training of teaching and research team in universities. At present, incentive system for teaching and research team in universities has various shortcomings, such as improper incentives, invalid incentives, unsatisfying effect, etc. [3, 4].

Problems of the Management Layer. In this part, the management layer who formulates the incentive policy is viewed as the incentive subject and the teaching and research team as well as members is the incentive objects.

Without a thorough understanding on current situations or education and adequate consciousness of talent competition, some universities neglect the incentive measures, resulting in brain drain and making vitality out of question. The management layer of some universities believes that teachers are hosts of universities and shall work positively, so it doesn't need any incentive measures to stimulate their potentials. Some university leaders view them as governors and only send commands to teachers instead of stimulating their enthusiasm, which will surely cause psychological imbalance of teachers and hurt enthusiasm of teachers, especially those in the teaching and research team.

Poor Communication between the Management Layer and the Teaching and Research Team. Universities often care about the up-to-down command transmission rather than the information feedback from low levels. The university management layer who is the maker of incentive system can only stimulate teachers' enthusiasm to the maximum extent with a deep understanding on demands for teaching and research team. Many universities copy incentive measures from other universities blindly. However, this is undesirable and it is necessary to make appropriate incentive measures based on scientific investigation on teams and teachers.

Poor Competence of the Teaching and Research Team. For various reasons, teachers in universities have different abilities and professional qualities, which will further decrease the team working ability of the teaching and research team. Therefore, teachers shall study hardly and keep up with the development of universities and the teaching and research team. Despite of individual achievements, a team emphasizes more on the team performance. It not only depends on collective decision-making, but also emphasizes on collaborative contributions of members. Hence, it is urgent to perfect the training and assessment systems for teaching and research team in universities, and promote individual and collaborative abilities of the team.

Low Working Enthusiasm of the Teaching and Research Team. Universities shall take low working enthusiasm of the teaching and research team seriously, train the sense of host completely and stimulate their working enthusiasm from the incentive system. Dedication means dutifully. A dedicated teacher will work hardly and can accomplish tasks excellently. Low working enthusiasm is accompanied with poor dedication of teachers. Therefore, university managers shall under psychology of teachers and make an incentive system meeting psychology of the teaching and research team. 


\section{Countermeasures and Reflections on Perfecting Incentive System for Teaching and Research Team in Universities}

The teaching and research team is not only the fresh troops for survival and development of universities, but also the wind indicator of transition and expansion of universities. An incentive to the teaching and research team is a hotspot in current management practice of universities. Problems of incentive system shall be taken into account when designing incentive measures and the incentive system shall be perfected from four aspects according to characteristics and job categories [5, 6].

Update Ideology of the Management Layer and Optimize Top-level Design of the Teaching and Research Team. Fundamentally, university institution is the key to establish and perfect incentive system for teaching and research team. Management layer is the top designer of management system of universities. Universities leaders shall change their management philosophy and optimize the existing incentive system. Firstly, they shall eliminate bureaucratic style and advocate democracy. Particularly, the teaching and research team will think of the university more sincerely if they get respects and positive responses from leaders. Secondly, university leaders shall put thoughts into practice, especially to performance of the teaching and research team. They shall make appropriate assessment according to practical situations.

Perfect the Subject-object Interaction Mechanism and Improve Working Efficiency of the Teaching and Research Team. The goal of the incentive system is to motivate initiatives of teachers. Comprehension of demands of the teaching and research team is the premise of making an appropriate incentive system. For the moment, university management is still influenced by the old management mode. The explicit structure and time and labor-consuming communication hinders understanding on demands of the teaching and research team. To realize the goal of efficient communication, universities can establish a direct communication system without middle parts and adopt informal communication channels. University managers can listen appeals of the teaching and research team and shorten distances with teachers, which is good for further understanding of their demands and desires.

Establish a Competence-based Incentive System and Increase the Overall Quality of the Teaching and Research Team. Dynamic growth of knowledge growth is the precondition and basis of university reform and the key for sustainable development of universities. The fundamental responsibilities of the management layer are not only for teachers to play their competences, but also explore the innovative potentials of teachers continuously while increasing the knowledge.

Give challenge works to the teaching and research team. Since the teaching and research team of universities represent their technology and future, it must give members of the team challenging works. With the continuous development of modern technologies, teachers shall keep pace with the time. Teachers also enjoy themselves in the challenging work, which is an incentive to teachers.

Make career planning of the teaching and research team. Universities shall inform teachers in the teaching and research team about their prospect, so that teachers will make career planning and know their development opportunities in the team and even in the university. If universities can pay attentions to career planning of teachers, understand individual demands and development desires fully, offer opportunities for appropriate promotion according to practical situations, and integrate teachers' individual development with the university development, teachers will be motivated to devote themselves to the university [7].

Perfect the training system for the teaching and research team. In the era of knowledge economy, universities must give teachers some training opportunities, which will make them aware of the necessity to master the latest technologies. To establish a training system for the teaching and research team in universities, it shall insist to combination of short-term training and long-term training, combination of concentrated training and self-learning, combination of skill training and education training, combination of internal training and communication between universities, combination of domestic training and international training, aiming to improve knowledge level of core talents.

Optimize the assessment system for the teaching and research team. Except for rewards, pressure 
(or assessment) is needed. Assessment indexes can simplify performance assessment. Through index evaluation, teachers will strengthen knowledge updating and learning ability consciously, thus laying foundations for university innovation and sustainable development [8].

Train cooperation of the teaching and research team. The teaching and research team is a team which has the nature of collaborative contribution. To make collaborative contributions, a feasible and challenging goal that can stimulate enthusiasm of members is needed.

Optimize the Incentive System and Increase Working Enthusiasm of the Teaching and Research Team. To increase working enthusiasm of teachers, it is necessary to establish a target incentive system and make teaching and research goals with certain difficulty and challenge. Meanwhile, universities shall innovate technologies and management of the teaching and research team, connect them with their economic benefits, and give certain direct rewards and spiritual encouragement to the core subject and leader. This ensures the coexistence of pressure and motivation to teachers.

Establish a target incentive system. The target incentive system includes two aspects: 1) inform the teaching and research team about the university goal and their important role in the goal realization; 2) pay attention to combine the university goal and the individual goals of members in the teaching and research team and make teachers understand to achieve their individual goal in the university goal. For development, universities hope the teaching and research team to establish a goal that fit the university benefits mostly. However, over high goal is beyond the competence of the teachers and over low goal will reduce teachers' expect. Therefore, it is reasonable to set goals based on conditions of the university and teachers. In addition, it shall increase valence of reward goal, avoid randomness and single setting of reward goal, and set multiple reward ways by considering different demands of teachers based on deep investigation and careful analysis. In this way, the teaching and research team will have strong passion and responsibilities to the university and care for the university benefits and development $[9,10]$.

Establish a material incentive system. Material incentive is the most basic rewards to teachers. Material incentive mainly includes salary incentive and welfare incentive. The former one includes salaries, bonus and additional premiums. Bonus and additional premiums are important to the teaching and research team, which will stimulate innovation ability of elites to some extent. Key attentions shall be paid to that incentives to the teaching and research team must be more than those to common teachers and different incentives shall be given to different team members. Comprehensive material incentives shall be given to scientific research papers, awards, patent application and monograph publishing in the name of the team or individuals. The incentive system shall cover all fields of talent innovation.

Establish a spirit incentive system. Spirit incentives are as important as material ones. Adequate preferential promotion and reward shall be offered to teaching and research subjects, especially core talents. Besides, universities shall provide a good working environment, including good working place, essential tools, complete working information and coordination of related departments. This can maintain working enthusiasm of teachers. To create a harmonious atmosphere for teaching and research subjects, universities shall strengthen cultural construction, promote its spirit and core values, and invite team members in management and strategy and innovative goal setting. This can reflect university's attention on teachers, meet their sense of belongs, and increase their acceptance and responsibility to the university's decision and goal.

\section{Summary}

Based on incentive subject, incentive object and their relationship, this paper discusses problems in existing incentive system for the teaching and research team in universities and puts forward four suggestions: update ideology of the management layer and optimize the top-level design of the teaching and research team; perfect the subject-object interaction system and increase working efficiency of the team; establish an competence-based incentive system and improve the overall 
quality of the team; optimize the dynamic incentive system and increase working enthusiasm of the team.

This paper still has many shortages and cooperative studies by far-sighted researchers are needed.

\section{References}

[1] C. Yang: Journal of China Women's University, Vol. 21 (2012) No.6, p.110-113(In Chinese).

[2] Information on http://eprints.gla.ac.uk/129124/.

[3] C. Bachmann and M. Baumann: Applied Economics, Vol.48 (2016) No.29, p.2736-2755.

[4] A.G. Vásquez: Estudios Gerenciales, Vol.27 (2011) No.120, p.127-145.

[5] F. Sancho: Energy Policy, Vol.48 (2016) No.29, p.2736-2755.

[6] F. Sancho: Health Serv Res, Vol.51 (2016) No.6, p.2927-2933.

[7] S. LAZAR: Scientific Annals of the Alexandru Ioan Cuza University of Iasi : Economic Sciences Series, Vol.2010 (2010) No.LVII, p.207.

[8] E.Fernández, R.Pérez and Jesús Ruiz: Energy Policy, Vol.39 (2011) No.7, p.4253-4263.

[9] G.Simon and W. Mark: Trials, Vol.10 (2009) No.1, p.44.

[10] N.D. Bastian, H. Kang, P.M. Griffin and L.V. Fulton: IIE Transactions on Healthcare Systems Engineering, Vol.6 (2016) No.1, p.33-41. 